\title{
Effect of the temperament of dairy cows on lifetime production efficiency
}

\author{
W. Neja, A. Sawa, M. Jankowska, M. Bogucki, and S. Krezżel-Czopek \\ Department of Cattle Breeding, Faculty of Animal Breeding and Biology, University of Technology and Life \\ Sciences in Bydgoszcz, Bydgoszcz, Poland \\ Correspondence to: W. Neja (nejaw@utp.edu.pl)
}

Received: 15 June 2014 - Accepted: 24 February 2015 - Published: 19 May 2015

\begin{abstract}
The aim of this study was to analyse the effect of the temperament of cows on their lifetime production efficiency. Data on milk performance, longevity and culling reasons of 11629 Polish Holstein-Friesian cows were extracted from the SYMLEK database. Using the methodology of the Polish Federation of Cattle Breeders and Dairy Farmers, cow temperament was assessed as follows: 1 - calm; 2 - normal; and 3 - excitable or aggressive. Most cows showed a normal temperament (89.52\%). Over successive years of the evaluation, there were increases in the proportion of cows with a calm (from 2.98 to $6.85 \%$ ) and excitable temperament (from 7.50 to $8.27 \%$ ). Temperament was found to have a highly significant effect on first lactation milk yield, first lactation daily milk yield, milk yield per day of age, and milk yield per day of productive life. In cows with a calm temperament, first lactation milk yield was $621 \mathrm{~kg}$ higher than in cows with a normal temperament and $329 \mathrm{~kg}$ higher compared to excitable (aggressive) cows.
\end{abstract}

\section{Introduction}

Dairy cattle are kept under conditions that are far from natural. In European countries, dairy cows spend most of the year in buildings and are totally dependent on humans for their survival. According to Tumanowicz et al. (2009), a thorough knowledge of bovine behaviour is needed to create optimum living conditions for cattle. One of the factors affecting milk production is the behaviour of dairy cows, otherwise known as the temperament, which is defined as an animal's behavioural responses to handling by humans (Burrow, 1997; Sutherland et al., 2012). Being part of an animal's nature, temperament is genetically determined (for example, in Jersey cattle the heritability of temperament is 0.25 ) and plays a major role in contact with humans. In addition, temperament is a trait that seems stable over time (Kunowska-Slósarz and Slósarz, 2008; Le Neindre et al., 2004; Visscher and Goddar, 1995). Despite the difficulties in measuring temperament using different methods and determining its scope (Wolf and Weissing, 2010; Reale et al., 2010), efforts are made to find the relationship between animal temperament and productivity (Voisinet et al., 1997; Juhas and Strapak, 2005; Müller and Keyserlingk, 2006; Keyserlingk et al., 2009; Szentleleki et al., 2008; Hoppe et al., 2010).

The aim of this study was to analyse the effect of the milking behaviour (temperament) of cows on their lifetime production efficiency, based on a large body of data collected as part of performance testing of cows from the KujawskoPomorskie province (around $10 \%$ of the national population of performance-tested cows).

\section{Material and methods}

The experiment used data on milk performance, longevity and culling reasons of 11629 Polish Holstein-Friesian cows from the SYMLEK database. The animals represented the active population in Pomorze and Kujawy regions, first calved in 2006, were assessed for temperament, and were used or culled until the end of 2012. The following milking temperaments categories were accounted for, based on the methodology of the Polish Federation of Cattle Breeders and Dairy Farmers: 1 - calm; 2 - normal; and 3 - excitable or aggressive.

The following indicators of lifetime production efficiency were studied: days of milking, first lactation daily milk yield 
Table 1. Production efficiency of cows depending on their milking behaviour (temperament).

\begin{tabular}{|c|c|c|c|c|}
\hline \multirow[t]{3}{*}{ Indicators } & \multicolumn{3}{|c|}{ Temperament } & \multirow{3}{*}{$\begin{array}{l}\text { IR (significance } \\
\text { of differences) }\end{array}$} \\
\hline & calm & normal & $\begin{array}{l}\text { excitable, } \\
\text { aggressive }\end{array}$ & \\
\hline & 1 & 2 & 3 & \\
\hline First lactation milk yield (kg) & 8412 & 7791 & 8083 & $1-2^{* *}$ \\
\hline Length of first lactation (days) & 373 & 372 & 366 & $\mathrm{~ns}$ \\
\hline First lactation daily milk yield (kg) & 22.7 & 21.1 & 22.2 & $1-2^{* *}$ \\
\hline Lifetime milk yield (kg) & 23345 & 21308 & 22132 & $1-2^{*}$ \\
\hline Lifespan (year) & 5.41 & 5.22 & 5.15 & ns \\
\hline Length of productive life (years) & 3.12 & 2.96 & 2.91 & ns \\
\hline Number of calvings & 2.87 & 2.74 & 2.73 & ns \\
\hline Milk yield/day of age (kg) & 11.1 & 10.3 & 10.8 & $1-2^{* *}$ \\
\hline Milk yield/day of productive life $(\mathrm{kg})$ & 20.7 & 19.7 & 20.8 & $1-2^{* *}$ \\
\hline
\end{tabular}

and lactation yield $(\mathrm{kg})$, lifetime milk yield (the sum of yields in individual complete lactations), lifespan (date of culling date of birth), length of productive life (date of culling - date of first calving), number of calvings throughout life, milk yield per day of age (lifetime yield/lifespan), and milk yield per day of productive life (lifetime yield/length of productive life).

The statistical analysis included cows under continuous evaluation.

Analysis of variance (GLM procedure of SAS) was used to evaluate the effect of cow temperament on the indicators of lifetime production efficiency. Significant differences were analysed with the Scheffe test (SAS, 2013). This analysis was based on following linear model:

$Y_{i j}=\mu+a_{i}+e_{i j}$

where $Y_{i j}$ is the value for a given trait, $\mu$ is the total mean, $a_{i}$ is the effect of temperament $(1,2,3)$ and $e_{i j}$ is the random error.

A chi-square test of independence (SAS, 2013) was used to analyse percentage of cows that were alive at the end of data collection (5 December 2012), sold, and culled for reasons specified by the SYMLEK system: low milk yield, udder diseases, infertility and reproductive diseases, infectious diseases (including leukaemia), old age, metabolic and digestive disorders, respiratory diseases, diseases of the locomotor system, accidents, and others (depending on the temperament).

In addition, data were extracted from the SYMLEK database on the number of Polish Holstein-Friesian cows representing the active population in Pomorze and Kujawy and evaluated for temperament, and the percentage of calm, normal and excitable (aggressive) cows in the 2006-2011 period was calculated.

\section{Results}

The temperament was found to have an effect $(P \leq 0.01)$ on first lactation milk yield, first lactation daily yield, and milk yield per day of age and day of productive life (Table 1). In cows with a calm temperament, first lactation milk yield was $621 \mathrm{~kg}$ higher than in cows with a normal temperament and $329 \mathrm{~kg}$ higher compared to excitable (aggressive) cows. First lactation daily milk yield ranged from 21.1 (normal temperament) to $22.7 \mathrm{~kg}$ (calm temperament). Slightly lower values were obtained for the milk yield per day of productive life. Cows with a higher score for the temperament showed a tendency for shorter first lactation, lifespan and length of productive life, and a lower number of calvings, but the differences were not significant. Most cows showed a normal temperament $(89.52 \%)$, followed by excitable (aggressive) temperament $(7.5 \%)$ and calm temperament $(2.98 \%)$ (Table 2). Among the cows that were alive and culled for old age, the highest proportion was formed by cows with a calm temperament (14.12 and $1.15 \%$, respectively), which confirms the longevity data presented in Table 1 . In the analysed population, regardless of the temperament, the most frequent culling reasons were infertility and reproductive diseases; this was the most frequent cause of culling excitable and aggressive cows $(34.98 \%)$. Excitable and aggressive cows were also more frequently culled than others due to accidents $(12.61 \%)$, metabolic and digestive disorders $(6.77 \%)$ and other reasons $(8.03 \%)$. Over successive years of the evaluation (2006-2011), there were increases in the proportion of cows with a calm (from 2.98 to $6.85 \%$ ) and excitable temperament (from 7.50 to $8.27 \%$ ) (Table 3). In 2011, there were almost $5 \%$ fewer cows with a normal temperament compared to 2006 . 
Table 2. Proportion of cows alive, sold and culled (with regard to culling reason) depending on their milking behaviour (temperament).

\begin{tabular}{lllll}
\hline Item & $\begin{array}{l}\text { Number of } \\
\text { cows }\end{array}$ & \multicolumn{2}{c}{$\begin{array}{l}\text { Proportion }(\%) \text { of cows depending on their } \\
\text { temperament (chi square }=43.96^{\mathrm{xx}} \text { ) }\end{array}$} \\
\cline { 3 - 5 } & & calm & normal & $\begin{array}{l}\text { excitable, } \\
\text { aggressive }\end{array}$ \\
\cline { 3 - 5 } & & 1 & 2 & 3 \\
\hline Total & 11629 & 2.98 & 89.52 & 7.50 \\
Alive & 1234 & 14.12 & 10.60 & 9.40 \\
Sold for further breeding & 633 & 4.03 & 5.65 & 3.56 \\
Culled due to: & & & & \\
Low milk yield & 158 & 1.44 & 1.34 & 1.61 \\
Udder diseases & 1497 & 14.41 & 12.80 & 13.19 \\
Infertility and reproductive disorders & 3913 & 33.72 & 33.54 & 34.98 \\
Infectious diseases (incl. leukaemia) & 385 & 0.29 & 3.45 & 2.87 \\
Old age & 65 & 1.15 & 0.51 & 1.03 \\
Metabolic and digestive disorders & 733 & 4.90 & 6.31 & 6.77 \\
Respiratory diseases & 23 & 0.86 & 0.17 & 0.23 \\
Locomotor diseases & 686 & 6.05 & 5.91 & 5.73 \\
Accidents & 1406 & 11.53 & 12.07 & 12.61 \\
Other & 895 & 7.49 & 7.68 & 8.03 \\
\hline
\end{tabular}

Table 3. Proportion of cows with a specific temperament (milking behaviour) over successive years of evaluation.

\begin{tabular}{lllll}
\hline Year & $\begin{array}{l}\text { Number of } \\
\text { cows }\end{array}$ & \multicolumn{3}{c}{$\begin{array}{c}\text { Proportion (\%) of cows } \\
\text { depending on temperament }\end{array}$} \\
\cline { 3 - 5 } & & calm & normal & $\begin{array}{l}\text { excitable, } \\
\text { aggressive }\end{array}$ \\
\cline { 3 - 5 } & & 1 & 2 & 3 \\
\hline 2006 & 11629 & 2.98 & 89.52 & 7.50 \\
2007 & 11347 & 4.20 & 88.86 & 6.94 \\
2008 & 11836 & 4.81 & 88.42 & 6.78 \\
2009 & 11252 & 5.14 & 86.40 & 8.46 \\
2010 & 12274 & 6.86 & 85.06 & 8.08 \\
2011 & 9586 & 6.85 & 84.74 & 8.27 \\
\hline
\end{tabular}

\section{Discussion}

Large individual differences in animal behaviour and their interpretation pose a considerable difficulty in cattle behaviour research regardless of the housing system, environmental conditions and the natural patterns of animal behaviour. On the other hand, behavioural observations in cattle are increasingly accurate and their analysis is increasingly taken into consideration when developing animal production technologies. This is decisive for practical breeding, where there is not only interest in understanding cattle behaviour but also special emphasis placed on its relationship with production traits and their genetic level (Tumanowicz et al., 2009; Adamczyk et al., 2011).

Personality has been shown to influence the productivity of cattle. In Bos taurus animals, for example, fearfulness in dairy cattle, assessed by a standard approach test, was significantly correlated with productivity, such as lower milk yield, milk protein and fat content (Müller and Keyserlingk, 2006).

Temperament is a trait that is closely related to the productivity of animals. This trait is difficult to evaluate and standardize, and its measurements are considered subjective (Kunowska-Slósarz and Slósarz, 2008). In our study, temperament had an effect $(P \leq 0.01)$ on the milk yield of cows. Arave and Kilgour (1982) showed a relationship between temperament and daily and lifetime milk yield, but found no correlation with lactation length. Kruszyński et al. (2013) estimated positive correlations between temperament and the yield of milk $\left(r_{G}=0.07\right)$, fat $\left(r_{G}=0.08\right)$ and protein $\left(r_{G}=0.09\right)$. According to Kunowska-Slósarz and Slósarz (2008), because selection for a calm temperament may increase the profit from milk production, breeders 
should account for animal temperament in dairy cattle production. At the same time, Gergovska et al. (2012) reported higher milk yields in cows with nervous and very nervous reactions during milking. The average yield of nervous and very nervous cows was higher than that of cows with an intermediate and calm temperament. This difference was $744.8 \mathrm{~kg}$ for Holstein-Friesians and $445.2 \mathrm{~kg}$ for Brown Swiss cows.

Other studies (Keyserlingk et al., 2009; Kahanna and Sharma, 1988; Purcell et al., 1988) found no relationship between milk production and cow temperament. According to Le Neindre et al. (2004), behavioural indicators play an important role in welfare assessment along with physiological, health and productive indicators. In addition, their importance increases with the increasing intensification of animal husbandry (Keyserlingk et al., 2009). The high proportion of cows with a normal temperament $(89.52 \%)$ in the analysed population may suggest that they were kept in welfare-friendly conditions. In a study concerning the effect of temperament in Jersey and Holstein-Friesian cows on milk production and somatic cell count, Orban et al. (2011) reported that Jersey cows were more docile and had a lower milk somatic cell count compared to Holstein-Friesian cows. Based on analysis of temperament on a five-point scale, the same authors found $50.9 \%$ of Jersey cows to be very calm, $42.8 \%$ calm and $6.3 \%$ less calm. There were no aggressive or very aggressive animals among Jersey cows. In Holstein-Friesians, as few as $1.5 \%$ were evaluated as very calm, $40.6 \%$ as calm, $42.0 \%$ as less calm and $15.9 \%$ as aggressive. In a study by Gergovska et al. (2012), the average temperament score (on a scale of 1 (very nervous) to 5 (very calm)) was slightly higher for Holstein-Friesian compared to Brown Swiss cows (3.74 and 3.65, respectively).

In our study we found no statistically significant effect of the temperament on cow longevity, measured using various indicators, but the longest lifespan and productive lifetime and the greatest number of calvings were observed in cows with a calm temperament. Sewalem et al. (2010) found a statistically significant relationship between milking temperament and the culling rate. Very nervous cows were 26, 23 and $46 \%$ more likely to be culled compared to very calm cows in Holstein, Ayrshire and Jersey breeds, respectively. According to Galindo and Broom (2000), the incidence of lameness among Holstein-Friesian cows increased with increasing total standing time.

It is concluded that milk yield, first lactation daily milk yield, and milk yield per day of age and day of productive life all depend on the cow's temperament. Most of the cows in the analysed population exhibited a normal temperament, but the proportion of animals with a calm and excitable temperament increased over successive years. The evaluation of the effects of cow behaviour on performance could help to find welfare indicators in farm animals.
Edited by: A.-E. Freifrau von Tiele-Winckler

Reviewed by: four anonymous referees

\section{References}

Adamczyk, K., Słania, A., Gil, Z., Felenczak, A., and Bull, J.: Relationship between milk performance and behaviour of cows under housing conditions, Ann. Anim. Sci., 11, 283-293, 2011.

Arave, C. W. and Kilgour, R.: Differences in grazing and milking behavior in high and low breeding index cows, Proc. NZ Soc. Anim. Prod., 42, 65-67, 1982.

Burrow, H. M.: Measurements of temperament and their relationships with performance traits of beef cattle, Anim. Breed. Abstr., 65, 477-495, 1997.

Galindo, F. and Broom, D. M.: Relationship between social behavior of dairy cows and the occurrence of lameness in three herds, Res. Vet. Sci., 69, 75-79, 2000.

Gergovska, Z., Miteva, T., Angelova, T., Yordanova, D., and Mitev, J.: Relation of milking temperament and milk yield in Holstein and Brown Swiss cows, Bulg. J. Agric. Sci., 18, 771-777, 2012.

Hoppe, S., Brandt, H. R., König, S., Erhardt, G., and Gauly, M.: Temperament traits of beef calves measured under field conditions and their relationships to performance, J. Anim. Sci., 88, 1982-1989, 2010.

Juhas, P. and Strapak, P.: The temperament measurement in the dairy cattle, in: 4th International Congress on Ethology in Animal Production, Agroinstitut Nitra, Slovakia, 19-21 October, 2005.

Keyserlingk, G., Rushen, J., de Passille, A. M., and Weary, D. M.: The welfare of dairy cattle - key concepts and the role of science, J. Dairy Sci., 92, 4101-4111, 2009.

Khanna, A. S. and Sharma, J. S.: Association of dairy temperament score with performance in some Indian breeds and crossbred cattle, J. Dairy. Sci., 58, 237-242, 1998.

Kruszyński, W., Pawlina, E., and Szewczuk, M.: Genetic analysis of values, trends and relations between conformation and milk traits in Polish Holstein-Friesian cows, Arch. Tierz., 56, 1-16, 2013.

Kunowska-Slósarz, M. and Slósarz, J.: Znaczenie temperamentu w hodowli bydła mięsnego [Importance of temperament in beef cattle breeding], Med. Wet., 64, 20-23, 2008 (in Polish).

Le Neindre, P., Guemene, D., Arnould, C., Leterrier, C., Faure, J. M., Prunier, A., and Meunier-Salaun, M. C.: Space, environmental design and behavior: Effect of space and environment on animal welfare, Proc. Global conference on animal welfare: an OIE initiative, Paris, 23-25 February 2004, 134-140, 2004.

Müller, R. and Keyserlingk, A. A. G.: Consistency of flight speed and its correlation to productivity and to personality in Bos taurus beef cattle, App. Anim. Behav. Sci., 99, 193-204, 2006.

Orban, M., Kovacsne, K. G., Pajor, F., Szentleleki, A., Póti, P., Tozer, J., and Gulyas, L.: Effect of temperament of Jersey and Holstein Friesian cows on milk production traits and somatic cell count, Arch. Tierz., 54, 594-599, 2011.

Purcell, D., Arave, C. W., and Walters, J. L.: Relationship of three measures of behavior to milk production, Appl. Anim. Behav. Sci., 21, 307-313, 1988.

Reale, D., Dingemanse, N. J., Kazem, A. J. N., and Wright, J.: Evolutionary and ecological approaches to the study of prersonality, Phil. Trans. Soc. B., 365, 3937-3946, 2010. 
SAS Institute Inc.: SAS/STATR 9.3 User's Guide, Cary, NC, SAS Institute Inc, 2013.

Sewalem, A., Miglior, F., and Kistemaker, G.: Analysis of the relationship between workability traits and functional longevity in Canadian dairy breeds, J. Dairy Sci., 93, 4359-4365, 2010.

Sutherland, M. A., Rogers, A. R., and Verker, G. A.: The effect of temperament and responsiveness towards humans on the behavior, physiology and milk production of multi-parous dairy cows in a familiar and novel milking environment, Physiol. Behav., 107, 329-337, 2012.

Szentleleki, A., Herve, J., Pajor, F., Falta, D., and Tozser, J.: Temperament of Holstein Friesian cows in milking parlour and its relation to milk production, Acta Univ Agri et Silvicul Mend Brun, 56, 201-208, 2008.
Tumanowicz, J., Zachwieja, A., and Kruszyński, W.: Po co ten behawior. [What about with behaviour ?], Przeg. Hod., 10, 22-25, 2009 (in Polish).

Visscher, P. M. and Goddard, M. E.: Genetic parameters for milk yield, survival, workability, and type traits for Australian dairy cattle, J. Dairy Sci., 78, 205-220, 1995.

Voisinet, B. D., Grandin, T., Tatum, J. D., O'Connor, S. F., and Struthers, J. J.: Feedlot Cattle with calm temperaments have higher average daily gains than cattle with excitable temperaments, J. Anim. Sci., 75, 892-896, 1997.

Wolf, M. and Weissing, F. J.: An explanatory framework for adaptive personality differences, Phil. Trans. R. Soc. B, 365, 39593968, 2010. 